\title{
SKRINING BAKTERI PENGHASIL ENZIM AMILASE DARI SEDIMEN TAMBAK UDANG VANNAMEI (Litopenaeus vannamei)
}

\author{
Diva Triza Novitasari ${ }^{\mathrm{a}^{*}}$, Pujiono Wahyu Purnomo ${ }^{\mathrm{b}}$, Oktavianto Eko Jati ${ }^{\mathrm{b}}$, Diah Ayuningrum ${ }^{\mathrm{a}, \mathrm{c}}$ dan \\ Aninditia Sabdaningsih ${ }^{\mathrm{a}, \mathrm{c}}$ \\ aprodi Manajemen Sumberdaya Perairan, Fakultas Perikanan dan Ilmu Kelautan, Universitas Diponegoro, \\ Semarang

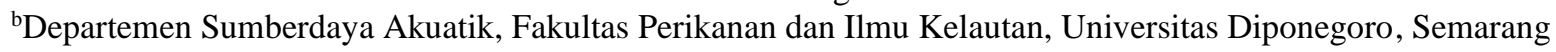 \\ 'Laboratorium Tropical Marine Biotechnology, Fakultas Perikanan dan Ilmu Kelautan, Universitas Diponegoro, \\ Semarang
}

*Koresponden penulis: divatriza@ gmail.com

\begin{abstract}
Abstrak
Tambak budidaya udang banyak memproduksi limbah organik yang berasal dari sisa metabolisme dan sisa pakan dari kultivan budidaya. Keberadaan limbah organik yang melimpah dan tidak didampingi dengan manajemen kualitas air, akan mengakibatkan dampak buruk pada kultivan seperti kematian. Proses bioremediasi termasuk salah satu cara untuk membersihkan bahan pencemar pada lingkungan tambak yang dibantu oleh agen biologis yaitu bakteri. Bakteri amilolitik dapat digunakan sebagai agen bioremediator pada lingkungan karena menghasilkan enzim amilase. Amilase merupakan enzim yang mampu menghidrolisis pati menjadi senyawa yang lebih sederhana. Penelitian ini bertujuan untuk mengisolasi bakteri dari sedimen tambak udang vanname dan melakukan skrining enzim amilase menggunakan media Starch Casein Nitrat (SCN). Sedimen diambil pada 5 lokasi tambak pasca panen di Kabupaten Rembang. Sampel diisolasi menggunakan teknik pour plate dan purifikasi dengan teknik streak plate, sedangkan skrining enzim dilakukan dengan teknik dotting. Hasil penelitian yang didapatkan menunjukkan bahwa terdapat 20 isolat bakteri yang diisolasi dari sedimen tambak udang vanname dan 9 isolat bakteri menunjukkan aktivitas enzim amilase, diketahui dari zona bening yang dihasilkan pada isolat setelah ditambahkan iodin. Topik ini dapat digunakan sebagai tambahan informasi mengenai bakteri sedimen yang dapat digunakan untuk membantu proses bioremediasi pada tambak udang seperti penelitian sebelumnya yang menggunakan actinomisetes sebagai agen bioremediator. Beberapa jenis isolat bakteri telah diidentifikasi menggunakan metode Polymerase Chain Reaction (PCR) mendapatkan bakteri berjenis Bacillus infantis dan Marinobacter koreensis.
\end{abstract}

Kata kunci: bakteri, bioremediasi, sedimen dan skrining enzim amilase

\begin{abstract}
Shrimp aquaculture ponds produce a lot of organic waste originating from metabolic waste and feed residue from cultivated cultivants. The existence of abundant organic waste and not accompanied by water quality management, will result in bad impacts on cultivants such as death. The bioremediation process is one of the ways to clean pollutants in the pond environment which is assisted by biological agents, namely bacterial microorganisms. Amylolytic bacteria can be used as bioremediator agents in the environment because they can produce amylase enzymes. Amylase is an enzyme capable of hydrolyzing starch into simpler compounds. This study aims to isolate bacteria from the sediments of vanname shrimp ponds and to screen for amylase enzymes using starch casein nitrate media. Sediment samples were taken from 5 post-harvest pond locations in Rembang Regency. The sample was isolated using the pour plate technique and purification using the streak plate technique, then enzyme screening was carried out using the dotting technique. The results obtained showed that there were 20 bacterial

(c)2021 at http://jfmr.ub.ac.id


isolates isolated from the sediment of vanname shrimp ponds and 9 bacterial isolates were known to be active in producing the amylase enzyme. Bacteria that actively produce amylase are known in the clear zone produced in isolates after adding iodine. This topic can be used as additional information about sedimentary bacteria that can be used to assist the bioremediation process in shrimp ponds such as previous studies that using actinmycetes as bioremediator agents. Some bacteria isolates that have been identified using the Polymerase Chain Reaction (PCR) method obtained the types of bacteria Bacillus infantis and Marinobacter koreensis.

Keywords: bacteria, bioremediation, screen amylase enzyme and sediment

\section{PENDAHULUAN}

Tambak budidaya merupakan salah satu kegiatan penghasil limbah yang berasal dari penumpukan bahan organik pada dasar perairan, limbah dapat dihasilkan dari pakan yang terbuang dan proses ekskreta hewan budidaya [1].

Perairan tambak sangat rentan terhadap kualitas air yang buruk, kondisi lingkungan tersebut banyak mengandung sisa bahan organik yang dapat menyebabkan dampak buruk pada suatu kultivan, salah satunya adalah penyakit. Kondisi kualitas air yang buruk dapat diatasi dengan mengelola kualitas air tambak, salah satunya adalah dengan bioremediasi [2]. Bioremediasi merupakan kegiatan penggunaan suatu mikroorganisme untuk menurunkan kadar polutan, dengan memanfaatkan produksi dari enzim-enzim yang dihasilkan oleh mikroorganisme yang sudah dipilih, hal ini dapat memodifikasi struktur polutan beracun menjadi suatu metabolit yang tidak beracun dan berbahaya [3].

Bakteri amilolitik berperan penting dalam pengolahan limbah yang banyak mengandung amilum dengan bantuan enzim amilase [4]. Enzim amilase merupakan suatu enzim yang mampu mengkatalis reaksi hidrolisis pati dan glikogen menjadi maltose, maltotriosa, isomaltosa dan glukosa [5]. Aktivitas bakteri yang menghasilkan enzim amilase dapat ditunjukkan melalui penambahan larutan iodin pada media agar yang mengandung pati, apabila terbentuk zona bening maka hal tersebut menunjukkan adanya aktivitas amilase [6]. Enzim amilase dapat memecah ikatan polimer pati menjadi lebih pendek, oligosakarida atau molekul gula yang lebih sederhana [7]. Penggunaan metode ini dipilih karena bahan mudah didapatkan dan tata caranya mudah dilakukan. Penelitian ini dilakukan untuk memberikan informasi terkait skrining bakteri penghasil enzim amilase yang dapat digunakan sebagai agen bioremediator dari sedimen tambak udang vanname.

\section{METODE PENELITIAN}

\section{Waktu dan Tempat}

Penelitian dilaksanakan pada bulan Juli 2020 hingga Januari 2021. Pengambilan sampel dilakukan pada 5 lokasi di tambak udang vanname pasca panen Rembang, Jawa Tengah. Adapun pengambilan sampel pada tambak udang tidak dikhususkan terhadap jenis tambak itu sendiri karena sampling dilakukan secara menyeluruh pada semua lokasi tambak. Perlakuan sampel dilakukan di Laboratorium Tropical Marine Biotechnology Universitas Diponegoro, Semarang.

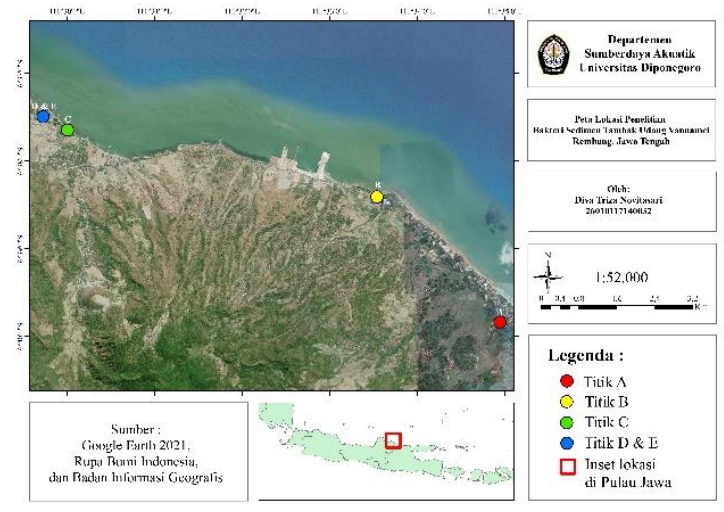

Gambar 1. Peta Lokasi Pengambilan Sampel di Rembang, Jawa Tengah

\section{Pengambilan Sampel}


Pengambilan sampel dilakukan menggunakan sekop sedimen pada lapisan atas permukaan, setelah sampel diambil kemudian dimasukkan dalam plastik steril dan disimpan dalam cool box selama 4 hari sebelum dilakukan proses lebih lanjut di laboratorium. Terdapat metode lain untuk mendapatkan sampel sedimen yaitu menggunakan sedimen grab [8] yang dimasukkan dalam perairan sesuai kedalaman yang diinginkan.

\section{Isolasi dan Purifikasi Bakteri}

Isolasi bakteri dari sedimen tambak udang vanname dilakukan dengan teknik pour plate [9] teknik ini dilakukan agar seluruh sel bakteri dapat tersebar merata ke seluruh media dan tidak hanya berada pada permukaan. Keunggulan metode pour plate ini dapat memperoleh biakan yang murni pada petri sedangkan kekurangannya yaitu apabila melakukan perhitungan maka hasil perhitungan tidak menunjukkan jumlah sel mikroba yang sebenarnya, dikarenakan beberapa sel yang berdekatan dapat membentuk satu koloni [10]. Purifikasi (pemurnian) dilakukan dengan teknik streak plate, teknik ini dilakukan untuk meremajakan kultur pada media yang baru [11]. Keunggulan metode streak plate dapat menghasilkan koloni bakteri yang tunggal, pola goresan dapat dibuat dengan pola tertentu dan bakteri kontaminan mudah untuk dibedakan [12]. Adapun kekurangan metode ini apabila dilakukan pada bakteri yang memiliki flagella maka akan membentuk koloni yang menyebar. Isolasi dan purifikasi dilakukan pada media IM 8 dengan komposisi malt extract $1 \mathrm{~g}$, glyserol $\left(\mathrm{C}_{3} \mathrm{H}_{8} \mathrm{O}_{3}\right)$ ROFA $1 \mathrm{~g}$, glukosa Merck KGaA $1 \mathrm{~g}$, peptone Himedia $1 \mathrm{~g}$, yeast Himedia $1 \mathrm{~g}$, agar Oxoid $20 \mathrm{~g}$ dan IM 6 dengan komposisi glycerol ROFA 0,25 ml, starch Merck KGaA 0,5 g, sodium propionote $0,5 \mathrm{~g}, \mathrm{KNO}_{3} 0,1 \mathrm{~g}$, asparagin $0,1 \mathrm{~g}$, casein $0,3 \mathrm{~g}, \mathrm{~K}_{2} \mathrm{HPO}_{4} 0,5 \mathrm{~g}, \mathrm{FeSO}_{4} \cdot 7 \mathrm{H}_{2} \mathrm{O}$ $1 \mathrm{mg}$ dan agar $20 \mathrm{~g}$ per $1000 \mathrm{ml}$ (50:50) akuades dan air laut [13]. Bahan-bahan pembuatan media disterilisasi menggunakan autoklaf pada suhu $121^{\circ} \mathrm{C}$ selama 20 menit. Setelah media selesai di autoklaf kemudian ditambahkan nystatin Novell sebagai anti jamur $75 \mu \mathrm{g} / \mathrm{ml}$
$(0,1 \%)$, nalidixic acid sebagai antibiotik 30 $\mu \mathrm{g} / \mathrm{ml}(0,1 \%)$ dan vitamin B complex $(0,1 \%)$.

Isolat bakteri yang berhasil diisolasi kemudian diamati karakter morfologinya secara makroskopis. Karakterisasi morfologi dilakukan dengan pengamatan melalui morfologi koloni tunggal yang meliputi bentuk, warna, tekstur, permukaan dan elevasinya [14].

\section{Skrining Enzim Amilase}

Hasil isolasi dan purifikasi kemudian di-dotting pada media SCN menggunakan tusuk gigi steril. Komposisi media SCN yaitu, starch Merck $\mathrm{KGaA} 10 \mathrm{~g}$, casein $1 \mathrm{~g}, \mathrm{KNO}_{3} 1 \mathrm{~g}$, $\mathrm{K}_{2} \mathrm{HPO}_{4} 0,5 \mathrm{~g}, \mathrm{MgSO}_{4} .7 \mathrm{H}_{2} \mathrm{O} 0,5 \mathrm{~g}, \mathrm{NaCl} 0,5 \mathrm{~g}$, FeSO4.7H2O 0,01 g, agar $20 \mathrm{~g}$ per $1000 \mathrm{ml}$; akuades dan air laut sebagai pelarut media. Inkubasi dilakukan selama 24 jam pada suhu ruang. Aktivitas enzim amilase ditunjukkan dengan terbentuknya zona bening pada media saat ditetesi dengan iodin [11].

\section{Karakterisasi Morfologi dengan Pengecatan Gram}

Metode yang dilakukan dalam pengecatan Gram antara lain adalah bakteri dioleskan diatas object glass, difiksasi lalu ditetesi dengan cat gram A, didiamkan selama 1 menit, ditetesi cat gram B, didiamkan selama 1 menit, ditetesi cat gram $\mathrm{C}$, didiamkan selama 30 detik, ditetesi cat gram $\mathrm{D}$, didiamkan selama 2 menit. Hasil yang sudah selesai ditutup dengan cover glass dan ditetesi minyak emersi untuk diamati bentuk dan warna sel melalui mikroskop [15].

\section{HASIL DAN PEMBAHASAN}

\section{Isolasi dan Purifikasi Bakteri}

Bakteri yang berhasil di isolasi dari sedimen tambak udang vanname yaitu sebanyak 20 isolat dengan karakter morfologi yang berbeda-beda. Hasil isolasi dan purifikasi ditunjukkan pada Tabel 1. 
Tabel 1. Hasil Identifikasi Morfologi dari Isolat Bakteri Sedimen Tambak Udang Vanname

\begin{tabular}{ccccc}
\hline Kode & Margin & Elevasi & Shape & Warna \\
\hline SA 1.2 & Wavy & Convex & Round & Kuning \\
SA 1.4 & Smooth & Convex & Round & Kuning \\
SA 3.1 & Smooth & Convex & Irregular & Putih \\
SA 3.1 & Wavy & Convex & Irregular & Kuning \\
SA 3.2 & Wavy & Convex & Irregular & Orange \\
SA 3.3 & Wavy & Convex & Irregular & Orange \\
SA 4.2 & Lobate & Flat & Round & Putih \\
SA 4.2 & Lobate & Flat & Round & Putih \\
SB 1.1 & Smooth & Convex & Round & Merah \\
SB 1.7 & Lobate & Umbonate & Irregular & Kuning \\
SB 1.8 & Smooth & Umbonate & Round & Putih \\
SC 2.4 & Smooth & Convex & Round & Kuning \\
SC 3.4 & Smooth & Flat & Round & Putih \\
SC 3.4 & Smooth & Raised & Round & Putih \\
SC 3.5 & Smooth & Umbonate & Round & Kuning \\
SC 3.5 & Smooth & Flat & Round & Putih \\
SE 1.1 & Lobate & Raised & Irregular & Putih \\
SE 1.2 & Smooth & Flat & Round & Kuning \\
SE 1.3 & Smooth & Flat & Round & Putih \\
SE 1.6 & Irregular & Raised & Irregular & Putih \\
\hline & & & &
\end{tabular}

\section{Skrining Enzim Amilase}

Hasil skrining enzim amilase dari bakteri sedimen tambak udang vanname ditunjukkan pada Tabel 2. Hasil terbentuknya zona bening dapat dilihat pada Gambar 2 .

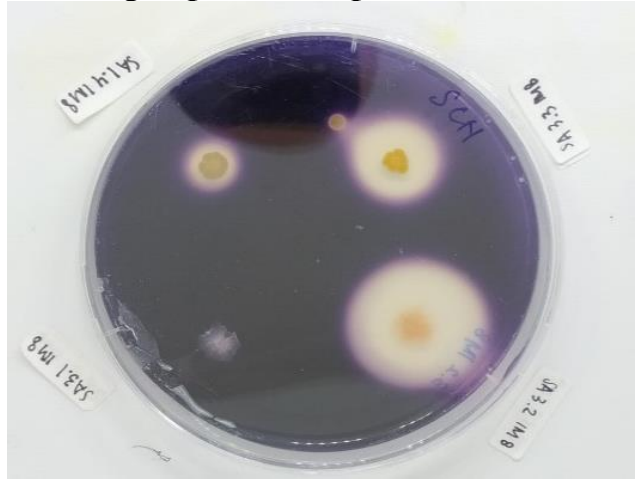

Gambar 2. Isolat bakteri SA 1.4, SA 3.3 dan SA 3.2 yang menunjukkan potensi menghasilkan enzim amilase.
Sekeliling koloni bakteri yang menghasilkan zona bening diakibatkan karena bakteri dapat menghidrolisis pati yang terkandung dalam media, sehingga pati yang terdegradasi tidak dapat lagi berikatan dengan $\mathrm{I}_{2}$ [16]. Bakteri yang menghasilkan enzim amilase dapat digunakan sebagai agen bioremediator pada lingkungan tambak, karena enzim amilase dinilai mampu mendegradasi dan mempercepat reaksi biokimia apabila disebar dalam kolam tanah dan air [17]. Isolat bakteri dengan aktivitas enzim yang paling potensial ditunjukkan pada bakteri yang memiliki zona bening sebesar $>10 \mathrm{~mm}$ (Tabel 2).

Tabel 2. Hasil Skrining Enzim Amilase

\begin{tabular}{ccccc}
\hline & & \multicolumn{2}{c}{ Hasil } & \\
\cline { 3 - 4 } Isolat & Media & Ulangan & Ulangan & Ket. \\
\hline SA 1.2 & IM 8 & + & ++++ & Aktif \\
SA 1.4 & IM 8 & +++ & ++++ & Aktif \\
SA 3.1 & IM 8 & - & - & Tidak Aktif \\
SA 3.1 & IM 6 & +++ & +++ & Aktif \\
SA 3.2 & IM 8 & ++++ & ++++ & Aktif \\
SA 3.3 & IM 8 & ++++ & ++++ & Aktif \\
SA 4.2 & IM 8 & ++++ & ++++ & Aktif \\
SA 4.2 & IM 6 & ++++ & ++++ & Aktif \\
SB 1.1 & IM 6 & ++++ & ++++ & Aktif \\
SB 1.7 & IM 8 & - & - & Tidak Aktif \\
SB 1.8 & IM 8 & - & - & Tidak Aktif \\
SC 2.4 & IM 6 & - & - & Tidak Aktif \\
SC 3.4 & IM 6 & - & - & Tidak Aktif \\
SC 3.4 & IM 8 & - & - & Tidak Aktif \\
SC 3.5 & IM 8 & - & - & Tidak Aktif \\
SC 3.5 & IM 6 & - & - & Tidak Aktif \\
SE 1.1 & IM 8 & - & - & Tidak Aktif \\
SE 1.2 & IM 8 & - & - & Tidak Aktif \\
SE 1.3 & IM 6 & - & - & Tidak Aktif \\
SE 1.6 & IM 8 & +++ & +++ & Aktif \\
\hline
\end{tabular}

Keterangan:

(+): aktivitas dengan ukuran kecil (1-3 mm) $(++)$ : aktivitas dengan ukuran sedang $(4-6 \mathrm{~mm})$

$(+++)$ : aktivitas dengan ukuran besar (7-10 mm) $(++++)$ : aktivitas dengan ukuran sangat besar $(>10 \mathrm{~mm})$ 


\section{Karakterisasi Morfologi dengan Pengecatan Gram}

Isolat bakteri yang memiliki potensi menghasilkan enzim amilase, kemudian di karakterisasi dengan pengecatan Gram. Hasil karakterisasi morfologi pada isolat bakteri ditunjukkan pada Tabel 3. Pengamatan pengecatan Gram melalui mikroskop dengan perbesaran 1000x dapat dilihat pada Gambar 3.

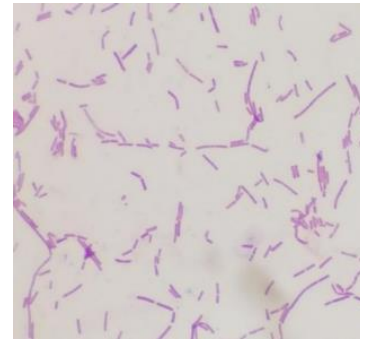

(a)

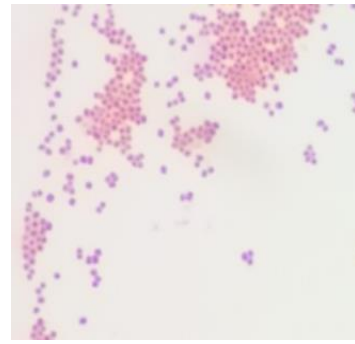

(b)
Gambar 3. Hasil pengecatan Gram pada isolat SA 3.2 (a) dan SA 3.3 (b), SA 3.2 menunjukkan hasil Gram positif dengan bentuk koloni basil dan SA 1.2 Gram positif dengan bentuk koloni coccus.

Hasil bakteri dengan Gram positif ditunjukkan perubahan warna menjadi ungu, sedangkan Gram negatif ditunjukkan perubahan warna menjadi merah. Bakteri Gram positif terjadi dikarenakan bakteri tetap mempertahankan warna kristal violet setelah diberi larutan alkohol, sedangkan bakteri Gram negatif mengambil warna merah dari safranin karena zat warna kristal violet larut saat diberi alkohol [18].

Tabel 3. Hasil karakterisasi morfologi dengan pengecatan Gram

\begin{tabular}{ccc}
\hline No & Kode Isolat & Keterangan \\
\hline 1 & SA 1.2 & Gram Positif \\
2 & SA 1.4 & Gram Negatif \\
3 & SA 3.1 & Gram Positif \\
4 & SA 3.2 & Gram Positif \\
5 & SA 3.3 & Gram Positif \\
6 & SA 4.2 & Gram Negatif \\
7 & SA 4.2 & Gram Negatif
\end{tabular}

\begin{tabular}{rrrr}
8 & SB 1.1 & \multicolumn{2}{c}{ Gram Positif } \\
9 & SE 1.6 & \multicolumn{2}{c}{ Gram Negatif } \\
\hline & Isolat & yang & berhasil diisolasi
\end{tabular}
menunjukkan kemampuan menghasilkan enzim amilase yang dapat digunakan untuk mendegradasi amilum pada limbah organik tambak budidaya seperti sisa pakan kultivan [1]. Hal ini menjadikan keberadaan bakteri ini sangat penting karena enzim yang dihasilkan dapat digunakan sebagai agen bioremediator apabila ditambahkan atau disebar dalam kolam tanah dan air [17].

Bakteri penghasil enzim amilase atau bakteri amilolitik ini paling besar didominasi oleh genus Bacillus [16], aktivitas enzimatik yang dimiliki oleh bakteri tersebut berkaitan dengan kemampuannya untuk menghasilkan karbohidrat [19].

\section{KESIMPULAN}

Bakteri dari sedimen tambak udang vanname telah berhasil diisolasi dan mendapatkan sebanyak 9 isolat berpotensi menghasilkan enzim amilase. Berdasarkan ukuran zona bening yang dihasilkan, terdapat isolat yang paling potensial menghasilkan enzim amilase yaitu pada SA 3.2 bakteri Gram positif berbentuk basil, SA 3.3 bakteri Gram positif berbentuk coccus, SA 4.2 bakteri Gram negatif berbentuk coccus dan SB 1.1 bakteri Gram negatif berbentuk coccus.

\section{UCAPAN TERIMA KASIH}

Penulis mengucapkan terima kasih kepada Lembaga Penelitian dan Pengabdian kepada Masyarakat Universitas Diponegoro Semarang yang telah mendanai penelitian ini dengan kontrak No. 233-83/UN7.6.1/PP/2021 dan Laboratorium Tropical Marine Biotechnology Universitas Diponegoro atas fasilitas yang tersedia sehingga penelitian ini dapat dilaksanakan dengan baik. Terima kasih kepada Prof. Dr. Ir. Suradi Wijaya Saputra, M.S 
selaku dosen penguji atas segala bimbingan dan arahan yang diberikan untuk penelitian ini.

\section{DAFTAR PUSTAKA}

[1] Setyati, W. A. dan Subagiyo. 2012. Isolasi dan Seleksi Bakteri Penghasil Enzim Ekstraseluler (Proteolitik, Amilolitik, Lipoitik, dan Selulolitik) yang Berasal dari Sedimen Kawasan Mangrove. Jurnal Ilmu Kelautan, 17 (3): 164-168.

[2] Elfidiah. 2016. Studi Kasus Optimalisasi Tambak Udang dari Pencemaran Amoniak $\left(\mathrm{NH}_{3}\right)$ dengan Metode Bioremediasi. Distilasi, 1 (1): 57-61.

[3] Priadie, B. 2012. Teknik Bioremediasi sebagai Alternatif dalam Upaya Pengendalian Pencemaran Air. Jurnal Ilmu Lingkungan, 10 (1): 3848.

[4] Silitonga, L. R., Nursyirwani dan I. Effendi. 2019. Isolation, Identification and Sensitivity of Amilolitic Bacteria from Mangrove Ecosystem Sediment in Purnama Marine Station Dumai on The Pathogenic Bacteria. Asian Journal of Aquatic Sciences, 2 (3): 257-266.

[5] Iswendi. 2010. Penentuan Aktivitas Amilase dari Umbi Bengkuang (Pachyrriuz arosus L.Urb) Hasil Ekstraksi dengan Etanol dan Amonium Sulfat. Jurnal Saintek, 11 (2): 94-98.

[6] Subagiyo, M. S. R. Djarod dan W. A. Setyati. 2017. Potensi Ekosistem Mangrove sebagai Sumber Bakteri Untuk Produksi Protease, Amilase, dan Selulase. Jurnal Kelautan Tropis, 20 (2): 106-111.

[7] Adnan, N., S. Wahyuni dan A. Khaeruni. 2017. Pengujian Sifat Amilolitik dan
Proteolitik dari Isolat Bakteri Asam Laktat (BAL) Hasil Fermentasi Air Cucian Beras Merah (Oryza nivara) Kultivar Wakawondu, JSTP, 2 (5): 759-769.

[8] Paena, M., R. A. Suhaimi dan M. C. Undu. 2017. Karakteristik Perairan Sekitar Tambak Udang Intensif saat Musim Hujan di Teluk Punduh Kabupaten Pesawaran Provinsi Lampung. Jurnal Ilmu dan Teknologi Kelautan Tropis, 9 (1): 221-234.

[9] Yunita, M., Y. Hendrawan dan R. Yulianingsih. 2015. Analisis Kualitatif Mikrobiologi Pada Makanan Penerbangan (Aerofood ACS) Garuda Indonesia Berdasarkan TPC (Total Plate Count) dengan Metode Pour Plate. Jurnal Keteknikan Pertanian Tropis dan Biosistem, 3 (3): 237-248.

[10] Damayanti, N. W. E., M. F. Abadi dan N. W. D. Bintari. 2020. Perbedaan Jumlah Bakteriuri pada Wanita Lanjut Usia Berdasarkan Kultur Mikrobiologi Menggunakan Teknik Cawan Tuang dan Cawan Sebar. Meditory, 8 (1): 1-4.

[11] Fitriasari, P. D., N. Amalia dan S. Farkhiyah. 2020. Isolasi dan Uji Kompatibilitas Bakteri Hidrolitik dari Tanah Tempat Pemrosesan Akhir Talangagung, Kabupaten Malang. Jurnal Ilmu-ilmu Hayati, 9 (2): 151-156.

[12] Dahlia, H. Suprapto dan R. Kusdarwati. 2017. Isolasi dan Identifikasi Bakteri pada Benih Ikan Kerapu Cantang (Epinephelus sp.) dari Kolam Pendederan Balai Perikanan Budidaya Air Payau (BPBAP) Situbondo, Jawa Timur. Journal Of Aquaculture and Fish Health, 6 (2): 57-66. 
[13] Santi, C. D., B. Altermark, D. D. Pascale dan N. P. Willassen. 2015. Bioprospecting Around Arctic Islands: Marine Bacteria as Rich Source of Biocatalysts. Journal Basic Microbiology, 56 (3): 238-253.

[14] Suryaningsih, V., R. S. Ferniah dan E. Kusdiyantini. 2018. Karakteristik Morfologi, Biokimia dan Molekuler Isolat Khamir IK-2 Hasil Isolasi dari Jus Buah Sirsak (Annoma muricataI L.). Jurnal Biologi, 7 (1): 18-25.

[15] Ibrahim, A., A. Fridayanti dan F. Delvia. 2015. Isolasi dan Identifikasi Bakteri Asam Laktat (BAL) dari Buah Mangga (Magnifera indica L.). Jurnal Ilmiah Manuntung, 1 (2): 159163.

[16] Zahidah, D. dan M. Shovitri. 2013. Isolasi, Karakterisasi dan Potensi Bakteri Aerob sebagai Pendegradasi Limbah Organik. Jurnal Sains dan Seni Pomits, 2 (1): 12-15.

[17] Setyati, W. A., A. S. Habibi, Subagiyo, A. Ridlo, S. Nirwani dan R. Pramesti. 2016. Skirining dan Seleksi Bakteri Simbion Spons Penghasil Enzim Ekstraseluler sebagai Agen Bioremediasi Bahan Organik dan Biokontrol Vibriosis pada Budidaya Udang. Jurnal Kelautan Tropis, 19 (1): 11-20.

[18] Nurhidayati, S., Faturrahman dan M. Ghazali. 2015. Deteksi Bakteri Patogen yang Berasosiasi dengan Kappaphycus alvarezii (Doty) Bergejala Penyakit Ice-ice. Jurnal Sains Teknologi dan Lingkungan, 1 (2): 24-30.

[19] Remijawa, E. S., A. D. N. Rupidara, J. Ngginak dan O. K. Radjasa. 2020. Isolasi dan Seleksi Bakteri Penghasil
Enzim Ekstraseluler pada Tanah Mangrove di Pantai Noelbaki. Jurnal Enggano, 5 (2): 164-180. 